\title{
Dirofilaria and Wolbachia in mosquitoes (Diptera: Culicidae) in central European Russia and on the Black Sea coast
}

\author{
Elena Shaikevich ${ }^{1, *}$, Anna Bogacheva ${ }^{2}$, and Ludmila Ganushkina ${ }^{3}$ \\ ${ }^{1}$ Vavilov Institute of General Genetics, Russian Academy of Sciences, Moscow 119991, Russia \\ ${ }^{2}$ Moscow State University, Moscow 119234, Russia \\ ${ }^{3}$ Martsinovsky Institute of Medical Parasitology, Tropical and Vector-Borne Diseases, Sechenov First Moscow State Medical University, \\ Moscow 119435, Russia
}

Received 5 October 2018, Accepted 4 January 2019, Published online 15 January 2019

\begin{abstract}
Dirofilariasis is endemic in Russia, as well as in many other European countries. The aim of this study was to assess the ability of mosquitoes to transfer Dirofilaria immitis and Dirofilaria repens in regions with temperate and subtropical climates. The possible impact of the symbiotic bacterium Wolbachia on Dirofilaria transmission was also investigated. 5333 female mosquitoes were collected at 11 points in central European Russia and on the Black Sea coast during the period 2013-2017. Out of 20 mosquito species examined, 14 were infected with D. repens and 13 with $D$. immitis. Both species of Dirofilaria were found in different climatic regions. The total Dirofilaria spp. estimated infection rate (EIR) in the central part of Russia varied from $3.1 \%$ to $3.7 \%$ and, in the southern region, from $1.1 \%$ to $3.0 \%$. The highest estimated infection rate was found in Anopheles messeae, the lowest in Culex pipiens. The greatest epidemiological danger was represented by Aedes aegypti, Ae. geniculatus, An. messeae and Ae. communis. Six out of 20 mosquito species were infected with Wolbachia. Pools of Aedes albopictus, Cx. pipiens and Coquillettidia richiardii were simultaneously infected with Dirofilaria and Wolbachia. After checking mosquitoes individually, it was found that there was no development of Dirofilaria to the infective larval stage in specimens infected with Wolbachia. Twenty-two Dirofilaria-infective pools were Wolbachia-free and only two mosquito pools were Wolbachia-infected. The potential for transmission of Dirofilaria in mosquito species naturally uninfected with the symbiotic bacterium Wolbachia is higher than in species infected with the bacterium.
\end{abstract}

Key words: mosquitoes, Dirofilaria repens, Dirofilaria immitis, Wolbachia pipientis.

Résumé - Dirofilaria et Wolbachia chez les moustiques (Diptera: Culicidae) en Russie centrale et sur la côte de la Mer Noire. La dirofilariose est endémique en Russie, ainsi que dans de nombreux autres pays européens. L'objectif de ce travail était d'étudier la capacité des moustiques à transférer Dirofilaria immitis et Dirofilaria repens dans les régions à climat tempéré et subtropical. L'impact possible de la bactérie symbiotique Wolbachia sur la transmission de Dirofilaria a également été étudié. 5333 moustiques femelles ont été collectés en 11 points en Russie centrale et sur la côte de la mer Noire au cours de la période 2013-2017. Sur les 20 espèces de moustiques examinées, 14 étaient infectées par $D$. repens et 13 par D. immitis. Les deux espèces de Dirofilaria ont été trouvées dans différentes régions climatiques. Le taux total d'infection estimé des Dirofilaria spp. dans la partie centrale de la Russie variait de 3,1 à 3,7 \% et de 1,1 à 3,0 \% dans le sud. Le taux d'infection estimé le plus élevé a été observé chez Anopheles messeae et le plus faible chez Culex pipiens. Le plus grand danger épidémiologique était représenté par Aedes aegypti, Ae. geniculatus, An. messeae et Ae. communis. Six espèces de moustiques sur 20 étaient infectées par Wolbachia. Des pools d'Aedes albopictus, Cx. pipiens et Coquillettidia richiardii étaient infectés simultanément par Dirofilaria et Wolbachia. Après avoir examiné les moustiques individuellement, il a été trouvé que les Dirofilaria ne se sont pas développés au stade larvaire infectant chez les spécimens infectés par Wolbachia. Vingt-deux pools infectés par Dirofilaria étaient indemnes de Wolbachia et seulement deux pools de moustiques étaient infectées par Wolbachia. Le potentiel de transmission de Dirofilaria chez les espèces de moustiques naturellement non infectées par la bactérie symbiotique Wolbachia est plus élevé que chez les espèces infectées par la bactérie.

*Corresponding author: elenashaikevich@mail.ru

This is an Open Access article distributed under the terms of the Creative Commons Attribution License (http://creativecommons.org/licenses/by/4.0), which permits unrestricted use, distribution, and reproduction in any medium, provided the original work is properly cited. 


\section{Introduction}

Dirofilariasis is a vector-borne disease common in many countries on various continents [27, 42, 44, 60]. Sources of infection for mosquitoes are infected dogs, less often cats and wild canines (wolves, foxes, etc.). Dirofilaria immitis and Dirofilaria repens are transmitted by culicid mosquito species belonging to the Culex, Aedes, Ochlerotatus, Anopheles, Coquillettidia, Armigeres and Psorophora genera [42, 58, 69]. Vectors ingest microfilariae during a blood meal on an infected host. In mosquito Malpighian tubules, microfilariae develop to the third stage larvae (L3) [34]. The season for Dirofilaria transmission in the central part of Russia begins in late May to early June [26]. In order for the larvae to develop to L3, a sum of temperatures of 130 degrees-day [27] is necessary. L3 reach the salivary glands and proboscis from where they are transferred while feeding to another host [34, 43]. However, development of larvae to the infective stage does not always occur; Dirofilaria remain in the Malpighian tubules and do not undergo further development or are encapsulated by the immune system of mosquitoes, and may also die within a few hours of entering the intestine of a mosquito [18, 34]. Thus, only mosquitoes in which development has progressed to the third stage larvae (L3) can be considered epidemiologically competent vectors, and the larvae, infective.

Dirofilaria infection is endemic in Russia. Two species of Dirofilaria (D. immitis and D. repens) have been identified in humans [54, 63]. Prior to 2014, D. repens infection was detected in 850 people living permanently in 42 regions of the Russian Federation [54]. The first case of D. immitis was detected in 2015 in the Moscow region; an immature female was removed from a 14-month-old child [63]. The dirofilariasis zone in the north of the European part of Russia has advanced to $58^{\circ} \mathrm{N}[4,10]$.

In Russia, mosquitoes infected with Dirofilaria have previously been investigated in the southern regions (Astrakhan, Rostov, Krasnodar Krai and Republic of Adygea) and the estimated infection rate (EIR) was 1.0\%-14.0\% [2, 24, 35]. Even though dirofilariasis is a concern in Russia, many areas have not been sufficiently studied. Also, there are no data on the species of mosquito that are potential vectors of dirofilarial worms. Identification of mosquitoes in all cases was conducted only to the genera level: $D$. immitis and D. repens have been detected in the Culex, Aedes and Anopheles genera and the EIR was established as $1.9 \%-7.0 \%, 2.3 \%-6.7 \%$, and $0.6 \%-3.4 \%$, respectively [2, 24, 35].

An endosymbiotic, maternally inherited bacterium, Wolbachia pipientis (Rickettsiales: Rickettsiaceae), hereafter Wolbachia, infects filarial nematodes and many insects, including some mosquito species. Wolbachia is required for the development and survival of filarial nematodes [61], whereas its symbiotic relationship with mosquitoes is largely parasitic [65]. Among the culicid mosquito species, Culex pipiens, Cx. quinquefasciatus and Ae. albopictus are known to be infected with Wolbachia [32, 67] and considered as vectors for Dirofilaria [13-15, 28, 45, 50, 69]. However, it was found that Culex pipiens f. molestus from Madeira, Portugal was unable to support the full development of $D$. immitis, both in nature and after experimental infection with D. immitis [29].
In continental Portugal, $C x$. pipiens were found to be infected with $D$. immitis, but were not potentially infective; filarial DNA was detected only in the abdomen and not in thorax-head samples [25]. However, D. immitis microfilariae development to the L3 stage has recently been found in the thorax-head of one Cx. pipiens f. pipiens from Spain [9]. The hypothesis concerning the influence of Wolbachia on the transmission of Dirofilaria by $C x$. pipiens mosquitoes in nature requires further confirmation, particularly in view of the limited number of infected specimens [9] and the absence of $100 \%$ Wolbachia infection of $C x$. pipiens in nature $[22,56]$. There are only three studies that have focused on investigating simultaneous infection with native Wolbachia and Dirofilaria in mosquitoes from natural populations $[22,23,51]$. Therefore, the effect of co-infection with native Wolbachia on mosquito vector competence for Dirofilaria remains unclear.

Prior to clarifying whether naturally occurring Wolbachia has any influence on filarial susceptibility or the development of Dirofilaria to the infective stage in the vectors, it is necessary to understand Wolbachia-mosquito interactions, which mosquito species are infected with the bacterium, the variability of bacterial strains, and the frequency with which Wolbachia occurs in mosquito populations.

The objectives of the current study were to examine mosquito fauna and to identify mosquito species that can potentially transmit filarial worms in rural and urban localities in the central part of European Russia compared with the Black Sea resorts, and to evaluate epidemiologically dangerous mosquito species in which larvae develop to the infective (L3) stage. All mosquito species were screened to determine their Wolbachia infection status.

\section{Materials and methods \\ Mosquito sampling and taxa discrimination}

Mosquitoes were captured in the Tula region, Nizhniy Novgorod region, Moscow region and on the Black Sea coast (Fig. 1, SM1). The climate in the studied regions in the central part of the country is moderately continental with clear seasonality; the average temperature in July is $+19{ }^{\circ} \mathrm{C}$, and in January $-10{ }^{\circ} \mathrm{C}$. At the resorts of the Black Sea coast, the climate is mild Mediterranean and subtropical with average temperatures in July of $+24{ }^{\circ} \mathrm{C}$ and in January $+3{ }^{\circ} \mathrm{C}$. Collection of mosquitoes in the central part of Russia was conducted throughout the warm season in 2013-2017, and in the southern part for one month at each point in 2012-2013 and 2016. Exact locations and months of gathering are presented in SM1.

Sampling locations in the Tula, Nizhniy Novgorod and Moscow regions were typical areas for a large number of dogs to be found (gardens of private houses, forests and parks) and natural forests as far as $6-8 \mathrm{~km}$ from rural and urban areas. At one of the sampling points in the Moscow region (\#5 Fig. 1), there was a kennel for stray dogs; this was located in the immediate vicinity of the forest where mosquito collections took place. To compare the infection rate of mosquitoes in urban and rural areas, we collected mosquitoes near human habitations and in forests. 


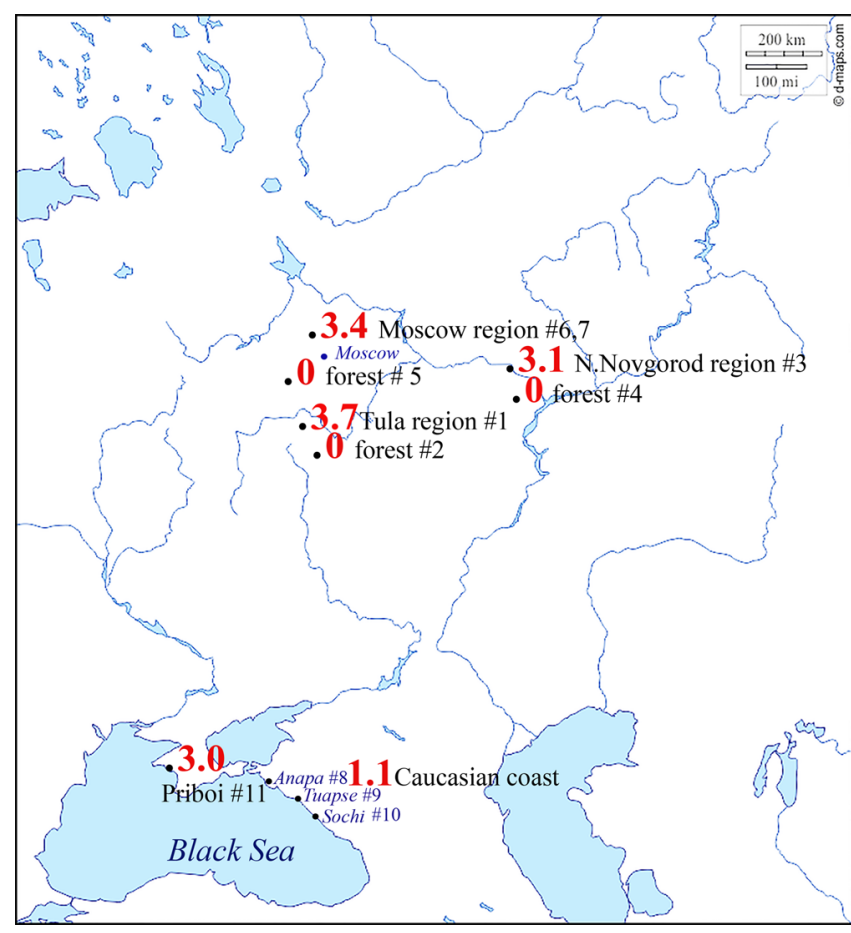

Figure 1. Map of mosquito sample sites and Dirofilaria infection rates (EIRs). EIR values for total $D$. immitis and $D$. repens are indicated in red. The exact names and geographical coordinates of the places of collection \#1-11 are presented in SM1.

Mosquito collection sites in the south were located in human settlements in a resort area. At the recreation centre "Priboi" (\#11 Fig. 1), lakes and ponds are located at a distance of $200-500 \mathrm{~m}$ from the collection site and flying mosquito imagoes were observed here. On the Black Sea coast of the Caucasus (\#8, 9, 10 Fig. 1) in Anapa, Tuapse and in Sochi, mosquitoes were collected in both urban and rural areas.

At all collection sites, the mosquitoes were captured using a suck tube by human landing during the most active attacking period from $6 \mathrm{pm}$ to $9 \mathrm{pm}$ several times during each month. After trapping, the mosquitoes were frozen at $-19{ }^{\circ} \mathrm{C}$ for 20-30 min and, afterwards, were identified using taxonomic keys [31]. The specific name of the tribe Aedini is presented according to the studies of Wilkerson et al. [66]. Identification of the molestus and pipiens forms of $C x$. pipiens and $C x$. torrentium was conducted genetically using a PCR-RFLP assay, based on the DNA variability of the COI gene, as described previously [55, 56]. Representatives of Anopheles maculipennis complex were identified using an ITS2 PCR-RFLP [47].

\section{Molecular Dirofilaria spp. screening}

The collected mosquitoes were grouped according to species, collection site and year; there were up to six specimens/pool, usually five. The thorax-head and abdomen of each mosquito in the group were dissected and formed the pool. In some cases, individual thorax-heads were analysed. DNA extraction was performed using the DIAtom ${ }^{\mathrm{TM}}$ DNA Prep kit (Isogen, Russia). Extraction was conducted separately for the abdomens and thorax-heads in order to determine infected and infective mosquito specimens, respectively. For the PCR analysis, we used 5333 female mosquitoes which were divided into 1095 pools. Each pool was tested separately to identify $D$. immitis and D. repens using the following primers: DIR-3: F-5'-CCGGTAGACCATGGCATTAT-3' and DIR-4: R-5'-CGGTCTTGG ACGTTTGGTTA-3' for the $D$. repens DNA repeat region [64] and COIintF - 5'-TGATTGGTGGTTTTGGTAA-3' and COIintR - 5'-ATAAGTACGAGTATCAATATC $-3^{\prime}$ for detection of the COI gene in the mtDNA of D. immitis [46]. The PCR was run on a GeneAmpR PCR System 2700 thermal cycler (Applied Biosystems, USA) with a GenPak PCR MasterMix Core PCR kit (Isogen, Russia) for amplification, according to the manufacturer's instructions. PCR was performed in 25-11 reaction mixtures, containing $1.5 \mathrm{mM}$ of $\mathrm{MgCl}_{2}, 10$ pmol of each primer and 20-50 ng of mosquito genomic DNA. PCR protocols were as follows: primary denaturing at $94{ }^{\circ} \mathrm{C}$ for $5 \mathrm{~min}$ and then 48 cycles of $94{ }^{\circ} \mathrm{C}$ for $30 \mathrm{~s}$, annealing at $50{ }^{\circ} \mathrm{C}$ for $30 \mathrm{~s}$ and extension at $72{ }^{\circ} \mathrm{C}$ for $60 \mathrm{~s}$, and a final extension at $72{ }^{\circ} \mathrm{C}$ for $5 \mathrm{~min}$ for $D$. repens; primary denaturing at $94{ }^{\circ} \mathrm{C}$ for $5 \mathrm{~min}$ and then 30 cycles of $94{ }^{\circ} \mathrm{C}$ for $1 \mathrm{~min}, 50{ }^{\circ} \mathrm{C}$ for $2 \mathrm{~min}$ and $72{ }^{\circ} \mathrm{C}$ for $3 \mathrm{~min}$, and final extension for $5 \mathrm{~min}$ at $72{ }^{\circ} \mathrm{C}$ for D. immitis. Negative and positive controls were used in each PCR analysis to avoid false-positive results. The positive control used in the study was obtained from adult $D$. repens isolated from a dog. The presence of filarial DNA was confirmed using $1.5 \%$ agarose gel electrophoresis. Resulting amplicon sizes were $656 \mathrm{bp}$ for D. immitis and $246 \mathrm{bp}$ for D. repens.

\section{Calculation of the infection rates}

Minimum infection rates (MIRs) were calculated using the following standard formula: (number of positive mosquito pools)/(total number of mosquitoes tested) $\times 100$ [13]. Estimated infection rates (EIRs) were calculated using the following formula: $1-(1-x / m) 1 / k$ [20], where $x$ is the number of positive pools, $m$ is the number of pools tested, and $k$ is the pool size. In the text, all EIRs are given per 100 specimens. Corresponding $95 \%$ confidence intervals (95\% CIs) were calculated by the modified Wald method, using GraphPad Scientific software. EIR values with corresponding 95\% CIs were calculated for all analysed pools per mosquito and Dirofilaria species. Host effectiveness was determined as the number of infectious mosquito pools with L3 larvae as a proportion of the total number of mosquitoes studied $\times 100$.

\section{Molecular Wolbachia screening}

Wolbachia infection was detected in a sub-sample of 2926 individuals (633 pools) of 20 mosquito species by PCR with an Encyclo PCR kit (Evrogen, Russia), using the $w s p$-specific primers wsp-81F and wsp-691R [8]. In cases where Dirofilaria DNA was detected in pooled abdomens from the mosquitoes, pools of abdomen and individual thorax-heads were tested for Wolbachia infection. In other cases, pooled mosquito thoraxheads were analysed. The PCR fragments were purified from agarose gel with a Clean-Up Extraction Kit (Evrogen, Russia) and were sequenced using the BigDye Termination kit 3.1 
(Applied Biosystems, USA) in order to distinguish Wolbachia of mosquito and of filarial nematode origins. Sequences of the Wolbachia wsp locus were deposited in GenBank under numbers MF989984-MF989989.

To distinguish between two strains of Wolbachia in Ae. albopictus, multi-primer PCR was used [70]; primers 383F and $183 \mathrm{~F}$ were paired with wsp-691R to allow the separation of wAlbA and wAlbB Wolbachia strains from Ae. albopictus. For the $w$ AlbA strain, a fragment size of $379 \mathrm{bp}$ was found and, for the $w$ AlbB strain, an amplicon length of 501 bp was found.

The $w$ Pip infections in $C x$. pipiens were genotyped in a subsample of 24 individuals representative of Dirofilaria-positive pools and assigned to the wPip-II and $w$ Pip-IV groups, using PCR-RFLP assays based on two $w$ Pip markers, ank2 and $p k 1$, as previously described $[3,56]$.

\section{Results}

\section{Dirofilaria spp. infection in mosquitoes}

The collected mosquitoes included 20 species; 16 species were in the central part of Russia and seven species on the Black Sea coast. The most abundant mosquito species in the temperate climate region was determined to be Ae. cantans. In the subtropical climate on the Black Sea coast, the most abundant sampled mosquito species was Ae. albopictus, followed by $C x$. pipiens and $C x$. modestus (Table 1). Filarial DNA was found in 15 species belonging to four genera with the total EIR for both Dirofilaria infections calculated as 2.71 (95\% CI, 2.18-3.03) (Table 2). The highest EIR values occurred with the species An. messeae, Ae. aegypti, Ae. geniculatus and Ae. cataphylla, and were estimated as 8.67, 5.33, 4.85 and 4.12 , respectively (Table 2). D. repens infected 14 of 15 mosquito species (EIR $=1.17,61$ positive pools) and D. immitis 13 species (EIR $=1.47,76$ positive pools). Both Dirofilaria species were found in one pool of Ae. cantans (twice), Ae. geniculatus (once), Cx. pipiens (once), Ae. intrudens (once) and $C q$. richiardii (once). More than one abdomen pool positive with D. repens was detected from Ae. cantans, Ae. cataphylla, Ae. intrudens and Ae. geniculatus; with D. immitis from Ae. cantans, Ae. intrudens, Ae. communis, Ae. albopictus, $C x$. pipiens, Ae. geniculatus, Cq. richiardii, Cx. modestus and Ae. cinereus (Table 2).

If we compare infection in the abdomen with the thoraxhead, D. immitis DNA was detected in $5.75 \%$ of tested abdomen pools and $1.37 \%$ of tested thorax-head pools. D. repens was found in $4.66 \%$ of tested abdomen pools and in $1.74 \%$ of tested thorax-head pools. The species Ae. cantans, Ae. geniculatus, Ae. communis and $C x$. modestus had more than one positive thorax-head pool (15, 5, 4 and 2 pools, respectively). Ae. cantans, Ae. communis and Ae. vexans had Dirofilaria in the abdomen and in the thorax-head in the same pools. In four species, Ae. cataphylla, Ae. leucomelas, Ae. excrucians and Ae. cinereus, microfilariae were only found in the abdomen, with EIR values of 1.51-4.12 (Table 2).

The EIR results for Dirofilaria in mosquitoes from specific collection sites are presented in an additional file (SM2). In the Nizhny Novgorod region (Fig. 1 \#3), EIRs for D. repens and
D. immitis were 1.23 and 1.92, respectively. In the Tula region (Fig. 1 \#1), EIRs for D. repens and D. immitis were 1.78 and 1.82, respectively. In the Moscow region (Fig. $1 \# 6,7$ ), the EIR for D. repens was 1.63 and for D. immitis 1.97, in a dog kennel in the forest near Moscow (Fig. 1 \#5) infected mosquitoes were not found. The first infected mosquitoes were recorded in May and the last in August-September. In the forest zones of the Nizhny Novgorod and Tula regions, with a sample of 525 specimens, no infected mosquitoes were found (SM2). At the resorts of the Caucasian Black Sea coast, in Anapa, Tuapse and Sochi (Fig. 1 \#8, 9, 10), the rates of mosquito infection were much lower; EIR values were 0.32 for $D$. repens and 0.81 for $D$. immitis. However, at the recreation center "Priboi" (Fig. 1 \#11), D. repens had an EIR of 0.99 and D. immitis 2.04; this is comparable to values in the central regions of Russia (Fig. 1).

\section{Wolbachia infection in mosquitoes}

The presence of Wolbachia was found in six out of 20 studied mosquito species. 93\% of all tested Cx. pipiens were infected with Wolbachia, followed by Cq. richiardii (68\%), Ae. albopictus (56\%), Ae. cinereus (37\%), Cx. modestus (7\%) and Ae. cantans (3\%). Specific sample sites and screening results are presented in an additional file (SM3). Sequences of Wolbachia wsp genes from all six mosquito species demonstrated that all bacteria belonged to supergroups A or B, which were shared between arthropods (Table 3). No filarial bacteria were amplified. Two Wolbachia strains were present in studied Ae. albopictus (wAlbA and $w \mathrm{AlbB}$ ), wPip-II in Cx. pipiens f. pipiens and $w$ Pip-IV in Cx. pipiens f. molestus. Based on the wsp gene sequence, Wolbachia strains in Cq. richiardii, Ae. cinereus and Ae. cantans differ from $w$ Alb and $w$ Pip, so we named these $w$ Crich, $w$ Acin and $w$ Ocan, respectively (pubmlst.org/wolbachia).

A total of 90 Dirofilaria positive abdomen and thoraxheads pools were analyzed for simultaneous infection with Wolbachia (Table 3). Seventy five of the Dirofilaria positive pools (83\%), including Ae. cinereus, Ae. cantans and Cx. modestus, were free from Wolbachia. Fifteen pools of Ae. albopictus, $C x$. pipiens and Cq. richiardii (17\%) were positive for both Wolbachia and at least one Dirofilaria species. Dirofilaria was found in 22 thorax-head pools of mosquitoes uninfected with Wolbachia and in two thorax-head pools which were positive for Wolbachia.

In order to investigate a possible association between the occurrence of Wolbachia and the development of Dirofilaria to the infective third larval stage (L3) within mosquitoes, we tested the thorax-heads of individual specimens from 12 pools: 25 individuals (five pools) of Ae. albopictus, 23 individuals (five pools) of Cx. pipiens (21 f. pipiens and two f. molestus), and 11 individuals (two pools) of $C q$. richiardii (SM4). There was no possibility to study one pool of Ae. albopictus (collected in Sochi 2012) infected with D. repens and two pools of $C x$. pipiens (collected in Tula 2014) - one infected with D. repens and one infected with $D$. immitis individually. The development of $D$. immitis to the infective stage (L3) was successful only in one thorax-head of Wolbachia-free Cq. richiardii (No. 11'-1, $\mathrm{SM} 4)$, although a pool of five mosquito abdomens gave a 
Table 1. Mosquito species composition and their collected numbers in studied regions.

\begin{tabular}{|c|c|c|c|c|c|c|c|c|}
\hline No. & Mosquito species & $\begin{array}{l}\text { Tula } \\
\text { region }\end{array}$ & $\begin{array}{c}\mathrm{N} . \\
\text { Novgorod } \\
\text { region }\end{array}$ & $\begin{array}{l}\text { Moscow } \\
\text { region }\end{array}$ & $\begin{array}{c}\text { Total in Central } \\
\text { European Russia }(\%)\end{array}$ & $\begin{array}{l}\text { Black Sea coast } \\
\text { Caucasus }\end{array}$ & $\begin{array}{c}\text { Crimean } \\
\text { peninsula, } \\
\text { Priboi }\end{array}$ & $\begin{array}{l}\text { Total in southern } \\
\text { regions }(\%)\end{array}$ \\
\hline 1 & Anopheles messeae (Falleroni) & 33 & 23 & 6 & $62(1.44)$ & 5 & 0 & $5(0.48)$ \\
\hline 2 & Coquillettidia richiardii (Ficalbi) & 57 & 87 & 3 & $147(3.42)$ & 25 & 12 & $37(3.57)$ \\
\hline 3 & $\begin{array}{l}\text { Aedes (Stegomyia) albopictus } \\
\quad \text { (Scuse) }\end{array}$ & 0 & 0 & 0 & 0 & 366 & 0 & $366(35.36)$ \\
\hline 4 & $\begin{array}{l}\text { Aedes (Stegomyia) aegypti } \\
\text { (Linnaeus) }\end{array}$ & 0 & 0 & 0 & 0 & 21 & 0 & $21(2.03)$ \\
\hline 5 & Aedes (Aedes) cinereus (Meigen) & 144 & 93 & 22 & $259(6.03)$ & 0 & 0 & 0 \\
\hline 6 & $\begin{array}{l}\text { Aedes (Aedimorphus) vexans } \\
\quad \text { (Meigen) }\end{array}$ & 125 & 46 & 8 & $179(4.16)$ & 0 & 0 & 0 \\
\hline 7 & $\begin{array}{l}\text { Aedes (Finlaya) geniculatus } \\
\quad \text { (Olivier) }\end{array}$ & 200 & 3 & 0 & $203(4.72)$ & 0 & 0 & 0 \\
\hline 8 & $\begin{array}{l}\text { Aedes (Ochlerotatus) cantans } \\
\quad \text { (Meigen) }\end{array}$ & 1140 & 337 & 299 & $1776(41.32)$ & 0 & 0 & 0 \\
\hline 9 & $\begin{array}{l}\text { Aedes (Ochlerotatus) communis } \\
\quad \text { (de Geer) }\end{array}$ & 88 & 67 & 152 & $307(7.14)$ & 0 & 0 & 0 \\
\hline 10 & $\begin{array}{l}\text { Aedes (Ochlerotatus) punctor } \\
\text { (Kirby) }\end{array}$ & 50 & 0 & 0 & $50(1.16)$ & 0 & 0 & 0 \\
\hline & $\begin{array}{l}\text { Aedes (Ochlerotatus) intrudens } \\
\quad \text { (Dyar) }\end{array}$ & 156 & 282 & 44 & $482(11.21)$ & 0 & 0 & 0 \\
\hline & $\begin{array}{l}\text { Aedes (Ochlerotatus) cataphylla } \\
\text { (Dyar) }\end{array}$ & 218 & 13 & 5 & $236(5.49)$ & 0 & 0 & 0 \\
\hline & $\begin{array}{l}\text { Aedes (Ochlerotatus) leucomelas } \\
\text { (Meigen) }\end{array}$ & 62 & 0 & 0 & $62(1.44)$ & 0 & 0 & 0 \\
\hline & $\begin{array}{l}\text { Aedes (Ochlerotatus) excrucians } \\
\text { (Walker) }\end{array}$ & 34 & 7 & 27 & $68(1.58)$ & 0 & 0 & 0 \\
\hline & $\begin{array}{l}\text { Aedes (Ochlerotatus) caspius } \\
\quad \text { (Pallas) }\end{array}$ & 0 & 0 & 0 & 0 & 140 & 6 & $146(14.11)$ \\
\hline & $\begin{array}{l}\text { Aedes (Ochlerotatus) diantaeus } \\
\text { (Howard, Dyar \& Knab) }\end{array}$ & 0 & 117 & 11 & $128(2.98)$ & 0 & 0 & 0 \\
\hline 17 & $\begin{array}{l}\text { Aedes (Ochlerotatus) sticticus } \\
\quad \text { (Meigen) }\end{array}$ & 54 & 0 & 3 & $57(1.33)$ & 0 & 0 & 0 \\
\hline 18 & Culex (Culex) pipiens (Linnaeus) & 270 & 9 & 0 & $279(6.49)$ & 70 & 167 & $237(22.89)$ \\
\hline 19 & Culex (Culex) torrentium (Martini) & 3 & 0 & 0 & $3(0.07)$ & 0 & 0 & 0 \\
\hline 20 & $\begin{array}{l}\text { Culex (Barraudius) modestus } \\
\quad \text { (Ficalbi) }\end{array}$ & 0 & 0 & 0 & 0 & 0 & 223 & $223(21.55)$ \\
\hline & Total & 2634 & 1084 & 580 & $4298(100)$ & 627 & 408 & $1035(100)$ \\
\hline
\end{tabular}

positive signal for both $D$. repens and $D$. immitis. Neither $D$. immitis nor $D$. repens were found in other individual thoraxheads; parasites were found only in pooled abdomens.

\section{Discussion}

\section{Mosquito species and Dirofilaria infection}

The detection of infection with $D$. repens and $D$. immitis was tested in 5333 mosquitoes comprising 1095 pools and representing 20 species collected in geographically remote locations in a temperate and sub-tropical climate. This is the first large-scale study of the infection of mosquitoes in the European part of Russia involving identification of the mosquito species. The published results on mosquito infestation in Europe, including Turkey, in comparison with our data are presented in Table 4. Previously, Ae. cataphylla, Ae. cinereus, Ae. excrucians, Ae. leucomelas, Ae. punctor and Ae. diantaeus mosquitoes were studied in Europe for the presence of Dirofilaria, but no positive samples were detected. In our study, infection with Dirofilaria was newly detected in the first four of these mosquito species. However, development of the larvae did not reach the infectious stage.

Ae. intrudens and Ae. communis were firstly studied here as vectors of Dirofilaria; their EIR values were 3.08 and 3.11, respectively. It should be noted that their epidemiological significance is confirmed by the presence of third-stage larvae in the thorax-heads. Ae. intrudens and Ae. communis host effectiveness was 0.41 and 1.3 , respectively.

Special attention should be paid to Ae. aegypti mosquitoes, which were found in Russia on the Black Sea coast of the Caucasus in 2000 [53]. As far as we know, the infection of natural populations of Ae. aegypti has not been studied. Based on a small sample (21 females), the EIR of this species of mosquitoes was reported as 5.33.

In our study, the most abundant species of mosquito was Ae. cantans (1776 specimens out of 5333) with an infection rate that was not high; the EIR for D. repens was 1.63 and for 
Table 2. Mosquito species and infection with D. immitis and D. repens.

\begin{tabular}{|c|c|c|c|c|c|c|c|c|c|c|c|c|}
\hline \multirow[t]{2}{*}{$\begin{array}{l}\text { Mosquito } \\
\text { species }\end{array}$} & \multirow{2}{*}{$\begin{array}{l}\text { Number of } \\
\text { indiv. } \\
\text { mosquitoes }\end{array}$} & \multirow[t]{2}{*}{$\begin{array}{l}\text { Number } \\
\text { of pools }\end{array}$} & \multirow{2}{*}{$\begin{array}{l}\text { Average } \\
\text { number of } \\
\text { specimens } \\
\text { per pool }\end{array}$} & \multicolumn{3}{|c|}{ Pools positive for $D$. repens } & \multicolumn{3}{|c|}{ Pools positive for $D$. immitis } & \multicolumn{3}{|c|}{$\begin{array}{l}\text { Total infection with either } D \text {. immitis and } \\
\text { D. repens }\end{array}$} \\
\hline & & & & $\begin{array}{l}\text { Number of } \\
\text { abdomen } \\
\text { pools }\end{array}$ & $\begin{array}{l}\text { Number of } \\
\text { head-thorax } \\
\text { pools }\end{array}$ & EIR $(95 \% \mathrm{CI})$ & $\begin{array}{l}\text { Number } \\
\text { of } \\
\text { abdomen } \\
\text { pools }\end{array}$ & $\begin{array}{l}\text { Number of } \\
\text { head-thorax } \\
\text { pools }\end{array}$ & EIR (95\% CI) & MIR (\%) & EIR $(95 \%$ CI $)$ & $\begin{array}{c}\text { Host } \\
\text { effectiveness } * * \\
(\%)\end{array}$ \\
\hline An. messeae & 67 & 15 & 4.47 & 1 & 1 & $3.15(0.21-10.86)$ & 3 & 0 & $\begin{array}{c}4.87(1.03- \\
12.87)\end{array}$ & 7.46 & $8.67(2.86-16.68)$ & 1.49 \\
\hline Ae. aegypti & 21 & 4 & 5.25 & 0 & 1 & $5.33(0.01-24.42)$ & 0 & 0 & 0 & 4.76 & $5.33(<0.01-24.42)$ & 4.76 \\
\hline Ae. geniculatus & 203 & 43 & 4.72 & 2 & 2 & $2.05(0.59-5.13)$ & 2 & 3 & $2.59(0.9-5.8)$ & 4.43 & $4.85(2.23-8.33)$ & 2.46 \\
\hline Ae. cataphylla & 236 & 49 & 4.82 & 6 & 0 & $2.67(1.04-5.56)$ & 3 & 0 & $1.3(0.26-3.85)$ & 3.81 & $4.12(1.91-7.19)$ & 0 \\
\hline Cq. richiardii & 184 & 40 & 4.6 & 2 & 0 & $1.11(0.04-4.13)$ & 3 & 1 & $2.27(0.65-5.65)$ & 3.26 & $3.47(1.34-7.09)$ & 0.54 \\
\hline Cx. modestus & 223 & 45 & 4.96 & 3 & 0 & $1.38(0.27-4.06)$ & 2 & 2 & $1.86(0.54-4.68)$ & 3.14 & $3.35(1.40-6.46)$ & 0.89 \\
\hline Ae. cantans & 1776 & 356 & 4.99 & $25\left(8^{*}\right)$ & $11\left(8^{*}\right)$ & $1.63(1.08-2.28)$ & $21(1 *)$ & $4(1 *)$ & $1.9(0.9-2.01)$ & 2.93 & $3.11(2.23-3.83)$ & 0.84 \\
\hline Ae. communis & 307 & 64 & 4.79 & $3(1 *)$ & $1^{*}$ & $0.99(0.2-2.97)$ & 3 & 3 & $2.03(0.8-4.3)$ & 2.93 & $3.11(1.47-5.56)$ & 1.3 \\
\hline Ae. intrudens & 482 & 98 & 4.92 & 4 & 1 & $1.06(0.37-2.48)$ & 8 & 1 & $1.94(0.93-3.57)$ & 2.9 & $3.08(1.69-4.86)$ & 0.41 \\
\hline Ae. vexans & 179 & 37 & 4.84 & 2 & 0 & $1.14(0.04-4.24)$ & $3(1 *)$ & $1^{*}$ & $1.73(0.35-5.04)$ & 2.79 & $2.96(1.02-6.55)$ & 0.56 \\
\hline Ae. cinereus & 259 & 54 & 4.79 & 1 & 0 & $0.39(<0.01-2.38)$ & 4 & 0 & $1.59(0.46-4.05)$ & 1.93 & $2.01(0.70-4.57)$ & 0 \\
\hline Ae. albopictus & 366 & 74 & 4.95 & 0 & 1 & $0.27(<0.01-1.69)$ & 5 & 0 & $1.4(0.49-3.25)$ & 1.64 & $1.69(0.67-3.62)$ & 0.27 \\
\hline Ae. leucomelas & 62 & 13 & 4.77 & 0 & 0 & 0 & 1 & 0 & $\begin{array}{c}1.66(<0.01- \\
9.41)\end{array}$ & 1.61 & $1.66(<0.01-9.41)$ & 0 \\
\hline Ae. excrucians & 68 & 15 & 4.53 & 1 & 0 & $1.51(<0.01-8.63)$ & 0 & 0 & 0 & 1.47 & $1.51(<0.01-8.63)$ & 0 \\
\hline$C x$. pipiens & 516 & 104 & 4.96 & 1 & 1 & $0.39(0.01-1.5)$ & 5 & 0 & $0.99(0.35-2.32)$ & 1.36 & $1.39(0.60-2.83)$ & 0.19 \\
\hline Ae. sticticus & 57 & 13 & 4.38 & 0 & 0 & 0 & 0 & 0 & 0 & 0 & 0 & 0 \\
\hline Ae. caspius & 146 & 30 & 4.87 & 0 & 0 & 0 & 0 & 0 & 0 & 0 & 0 & 0 \\
\hline Ae. punctor & 50 & 11 & 4.55 & 0 & 0 & 0 & 0 & 0 & 0 & 0 & 0 & 0 \\
\hline Ae. diantaeus & 128 & 27 & 4.74 & 0 & 0 & 0 & 0 & 0 & 0 & 0 & 0 & 0 \\
\hline$C x$. torrentium & 3 & 3 & 1 & 0 & 0 & 0 & 0 & 0 & 0 & 0 & 0 & 0 \\
\hline Total & 5333 & 1095 & 4.87 & $51\left(9^{*}\right)$ & $19(9 *)$ & $\begin{array}{l}1.17(0.89-1.47) \\
\quad \operatorname{MIR}=1.14\end{array}$ & $63(2 *)$ & $15\left(2^{*}\right)$ & $\begin{array}{l}1.47(1.14-1.78) \\
\quad \operatorname{MIR}=1.43\end{array}$ & 2.57 & $2.71(2.18-3.03)$ & 0.64 \\
\hline
\end{tabular}

*Inclusive pools, in which infection was detected in both abdomens and head-thorax pools;

*** Host effectiveness - proportion of infectious mosquitoes with L3 larvae in total number of studied mosquitoes (\%). 
Table 3. Positive pools for both Dirofilaria and Wolbachia. Bold, samples positive for Wolbachia.

\begin{tabular}{|c|c|c|c|c|}
\hline Species & $\begin{array}{l}\text { Pools positive for } \\
\text { D. repens (inclusive } \\
\text { heads) }\end{array}$ & $\begin{array}{c}\text { Pools positive for } \\
\text { D. immitis (inclusive } \\
\text { heads) }\end{array}$ & $\begin{array}{l}\text { Pools positive for } \\
\text { Wolbachia }\end{array}$ & $\begin{array}{l}\text { Wolbachia } \\
\text { supergroup }\end{array}$ \\
\hline Ae. cinereus & 0 & 1 & 0 & \\
\hline Ae. vexans & 1 & 0 & 0 & \\
\hline Ae. geniculatus & $4(2)$ & $5(2)$ & 0 & \\
\hline Ae. cantans & $26(9)$ & $9(3)$ & 0 & \\
\hline Ae. cataphila & 1 & 0 & 0 & \\
\hline Ae. intrudens & 2 & 6 & 0 & \\
\hline Ae. communis & $3(1)$ & 1 & 0 & \\
\hline Ae. excrucians & 1 & 0 & 0 & \\
\hline Ae. aegypti & (1) & 0 & 0 & \\
\hline Ae. albopictus & (1) & 5 & 6 & $A$ and $B$ \\
\hline An. messeae & $2(1)$ & 2 & 0 & \\
\hline Cq. richiardii & 1 & $4(1)$ & 2 & $\mathbf{B}$ \\
\hline Cx. pipiens s.l. & $2(1)$ & 4 & 7 & B \\
\hline Cx. modestus & 3 & $4(2)$ & 0 & \\
\hline Total & $48(16)$ & $41(8)$ & 15 & \\
\hline
\end{tabular}

D. immitis 1.39. Infection of $C q$. richiardii mosquitoes with D. immitis $(\mathrm{EIR}=2.27$ ) is comparable to data from Serbia [37] and Slovakia [11]. However, in Moldova [58], mosquitoes of these three species were infected with Dirofilaria to a greater extent than in our results for Russia (Table 4). In our study, Ae. strictus mosquitoes were not infected, in contrast with data from Serbia, Slovakia and especially from Moldova. The epidemiological significance of Ae. vexans, widely distributed in Europe, as a vector of Dirofilaria was minor. Its infection rate in different countries varied from 0.03 to 1.68 (Table 4). In Russia, in the Nizhny Novgorod region, there were no infected mosquitoes of this species; in Tula, D. repens was found with EIR of 0.81 and D. immitis with EIR 2.52. In the Moscow region, of a small sample of three Ae. vexans females, one was infected with $D$. repens. The infection rate with $D$. repens in $C x$. modestus and Ae. geniculatus was similar to infection of these mosquito species in Moldova [58]. The difference is that in our samples, both mosquito species were infected, not only with $D$. repens, but also with $D$. immitis.

In our study, the highest EIR value was found in An. messeae. Importantly, some An. messeae mosquitoes were collected in early May. The females that flew out after the winter diapause actively attacked both humans and dogs. In the Nizhny Novgorod region, 2 out of 12 females caught in May were infected with microfilariae. Somewhat different infection rates of this mosquito species were reported in Moldova (Table 4).

The lowest infection in our study was found in Ae. albopictus and Cx. pipiens. According to our data, Ae. albopictus mosquitoes were infected with $D$. repens with an EIR of 0.27 and, with D. immitis, an EIR of 1.4. In Italy, Ae. albopictus infected with $D$. repens $[13]$, with $D$. immitis $[28,41]$ and with both species [16] were found with MIR values ranging from 0.69 to 3.19 (Table 4). According to our results, $C x$. pipiens mosquitoes were infected with $D$. repens with EIR 0.39 and with $D$. immitis EIR 0.99. A comparable frequency was recorded in Italy, Turkey, Portugal, Germany, Moldova and the Republic of Belarus (Table 4).

Differences in infection rates in the same mosquito species from different regions could be connected with ecological factors, such as season, climate and geographical features, which are specific for each region [27], but also, perhaps to an even greater extent as shown by our results with Ae. aegypti, Ae. cantans and Ae. vexans, connected with the sample size.

\section{Infection in specific collection regions}

When comparing the total infection of mosquitoes with $D$. repens and $D$. immitis by region (SM2), almost identical EIR results in the settlements of the Central region were noted, with some prevalence of mosquitoes infected with $D$. immitis. On the Black Sea coast of the Caucasus (Fig. 1 \#, 9, 10), mosquitoes were collected in a resort area where the number of dogs near our sample sites was negligible and the infection of mosquitoes was lower. Temperature is an important factor for the maintenance of dirofilariasis foci. However, the presence of definitive hosts (mainly domestic, office and stray dogs) basically determines one or another level of mosquito infection with Dirofilaria. This is confirmed by the absence of infection in mosquitoes collected in the forest at a distance of 8-10 km from settlements in the Nizhny Novgorod and Tula regions (Fig. 1, "forests" \#2, 4). However, in the settlements (Fig. 1 \#1, 3, 6, 7), mosquito infection was high $>3 \%$. Possible reasons for this are that circulation of the pathogen in the two woodlands does not occur, or wild canines are not affected by Dirofilaria or are affected to such a small extent that we could not discern infectionby examining the mosquito vectors.

In the Moscow region, one point was studied in the immediate vicinity of the dog kennel (Fig. 1 \#5), located in a woodland $2 \mathrm{~km}$ away from the nearest settlement. Infected mosquitoes were not found. In this kennel, the dogs were treated for different infections, including Dirofilaria, and the infection from wild animals did not occur or was extremely low.

\section{Host effectiveness}

According to our findings, under similar conditions (temperature and the presence of definitive hosts), the effectiveness 
Table 4. Published results about Dirofilaria in mosquito species in Europe, including Turkey, in comparison with data obtained in this study.

\begin{tabular}{|c|c|c|c|c|c|}
\hline Species & $\mathrm{N}$ indiv./pools & D. repens & D. immitis & Host effectiveness & Country, references \\
\hline Cx. pipiens & $516 / 104$ & $\mathrm{EIR}=0.39$ & $\mathrm{EIR}=0.99$ & 0.19 & This study \\
\hline Cx. pipiens & $1108 / 412$ & $\mathrm{MIR}=0.27$ & $\mathrm{MIR}=0.27$ & $0.27 *$ & Italy $2002-2003[12]$ \\
\hline Cx. pipiens (s.1.)/torrentium & $2663 / 132$ & $\mathrm{EIR}=0.88$ & $\mathrm{EIR}=0.47$ & & Moldova 2010-2016 [58] \\
\hline$C x$. pipiens & $1595 / 1123$ & & $\mathrm{EIR}=0.50$ & & Continental Portugal 2011-2013 [25] \\
\hline$C x$. pipiens & 2589 & & $\mathrm{MIR}=0.12$ & $0.12 *$ & Turkey 2008-2009 [69] \\
\hline$C x$. pipiens & $37,865 / 835$ & $\mathrm{MIR}=0.01 *$ & $\operatorname{MIR}=0.04^{*}$ & & Italy 2010 [38] \\
\hline Cx. pipiens & $5568 / 115$ & $\operatorname{MIR}=0.02 *$ & $\operatorname{MIR}=0.18^{*}$ & & Serbia 2013 [37] \\
\hline Cx. pipiens complex & $2539 / 187$ & $\mathrm{MIR}=0.28^{*}$ & & & Slovakia $2015-2017$ [11] \\
\hline Cx. pipiens/Cx. torrentium & $12,292 / 554$ & & $\operatorname{MIR}=0.02 *$ & & Germany 2011-2013 [36] \\
\hline Cx. pipiens & $136 / 11$ & & $\mathrm{EIR}=0.58$ & & Belarus 2015 [59] \\
\hline Cx. pipiens & 666 & & $\mathrm{MIR}=0.3^{*}$ & & Spain 2004-2006 [46] \\
\hline Cx. pipiens & 604 & & $\mathrm{MIR}=0.17^{*}$ & $0.17 *$ & Spain 2012-2013 [9] \\
\hline An. messeae & $67 / 15$ & $\mathrm{EIR}=3.15$ & $\mathrm{EIR}=4.87$ & 1.49 & This study \\
\hline An. maculipennis s.l. & $400 / 114$ & & $\mathrm{EIR}=3.12$ & $1.25^{*}$ & Continental Portugal 2011-2013 [25] \\
\hline An. maculipennis & $136 / 28$ & $\operatorname{MIR}=1.47^{*}$ & & & Slovakia $2015-2017$ [11] \\
\hline An. maculipennis s.1. & $947 / 62$ & $\mathrm{EIR}=4.91$ & $\mathrm{EIR}=2.01$ & & Moldova 2010-2016 [58] \\
\hline Ae. vexans & $179 / 37$ & $\mathrm{EIR}=1.14$ & $\mathrm{EIR}=1.73$ & 0.56 & This study \\
\hline Ae. vexans & 3179 & & $\mathrm{MIR}=0.41$ & $0.35^{*}$ & Turkey 2008-2009 [70] \\
\hline Ae. vexans & $720 / 25$ & & $\mathrm{MIR}=0.14^{*}$ & & Italy 2010 [38] \\
\hline Ae. vexans & $405 / 19$ & $\mathrm{MIR}=0.25^{*}$ & & & Serbia 2013 [37] \\
\hline Ae. vexans & 12,042 & $\mathrm{MIR}=0.03$ & & & Czech Republic 2009-2011 [52] \\
\hline Ae. vexans & $314 / 33$ & $\mathrm{EIR}=1.68$ & & & Moldova 2010-2016 [58] \\
\hline Ae. vexans & $1750 / 35$ & $\mathrm{MIR}=0.06$ & & & Slovakia 2012 [7] \\
\hline Ae. vexans & $96 / 20$ & & $\mathrm{MIR}=1.04$ & & Turkey 2008 [6] \\
\hline Ae. caspius & $146 / 30$ & $\mathrm{EIR}=0$ & $\mathrm{EIR}=0$ & 0 & This study \\
\hline Ae. caspius & $26 / 13$ & $\mathrm{EIR}=22.64$ & & & Moldova 2010-2016 [58] \\
\hline Ae. caspius & $270 / 193$ & & $\mathrm{EIR}=3.73$ & $1.48^{*}$ & Continental Portugal 2011-2013 [25] \\
\hline Ae. caspius & $2264 / 92$ & & $\operatorname{MIR}=0.18^{*}$ & & Italy $2010[38]$ \\
\hline Ae. caspius & $195 / 13$ & & $\mathrm{MIR}=0.5^{*}$ & & Serbia 2013 [37] \\
\hline Cq. richiardii & $184 / 40$ & $\mathrm{EIR}=1.11$ & $\mathrm{EIR}=2.27$ & 0.54 & This study \\
\hline Cq. richiardii & $34 / 7$ & & $\mathrm{MIR}=2.94^{*}$ & & Serbia 2013 [37] \\
\hline Cq. richiardii & $48 / 26$ & & $\operatorname{MIR}=2.08^{*}$ & & Slovakia $2015-2017$ [11] \\
\hline Cq. richiardii & $19 / 11$ & $\mathrm{EIR}=16.25$ & & & Moldova 2010-2016 [58] \\
\hline Ae. cantans & $1776 / 356$ & $\mathrm{EIR}=1.63$ & $\mathrm{EIR}=1.39$ & 0.84 & This study \\
\hline Ae. cantans & $15 / 5$ & $\mathrm{EIR}=14.84$ & & & Moldova 2010-2016 [58] \\
\hline Ae. sticticus & $57 / 13$ & $\mathrm{EIR}=0$ & $\mathrm{EIR}=0$ & 0 & This study \\
\hline Ae. sticticus & $24 / 7$ & $\mathrm{EIR}=4.43$ & & & Moldova 2010-2016 [58] \\
\hline Ae. sticticus & $120 / 7$ & $\mathrm{MIR}=0.83^{*}$ & & & Serbia 2013 [37] \\
\hline Ae. sticticus & $414 / 41$ & $\mathrm{MIR}=0.24^{*}$ & $\mathrm{MIR}=0.24^{*}$ & & Slovakia $2015-2017$ [11] \\
\hline CX. modestus & $223 / 45$ & $\mathrm{EIR}=1.38$ & $\mathrm{EIR}=1.86$ & 0.89 & This study \\
\hline$C x$. modestus & $203 / 25$ & $\mathrm{EIR}=3.26$ & & & Moldova 2010-2016 [58] \\
\hline Ae. geniculatus & $203 / 43$ & $\mathrm{EIR}=2.05$ & $\mathrm{EIR}=2.59$ & 2.46 & This study \\
\hline Ae. geniculatus & $26 / 10$ & $\mathrm{EIR}=7.45$ & & & Moldova 2010-2016 [58] \\
\hline Ae. albopictus & $366 / 74$ & $\mathrm{EIR}=0.27$ & $\mathrm{EIR}=1.4$ & 0.27 & This study \\
\hline Ae. albopictus & $2534 / 336$ & 0 & $\mathrm{MIR}=3.19^{*}$ & $0.87 *$ & Italy $2000-2002[12,13]$ \\
\hline Ae. albopictus & $436 / 436$ & $\mathrm{MIR}=0.92 *$ & $\mathrm{MIR}=0.69^{*}$ & $1.15^{*}$ & Italy $2002-2003[16]$ \\
\hline Ae. albopictus & $528 / 98$ & & $\mathrm{MIR}=0.19^{*}$ & & Italy 2005 [41] \\
\hline Ae. albopictus & $175 / 35$ & & $\mathrm{MIR}=1.14$ & $0.51 *$ & Italy 2011 [28] \\
\hline
\end{tabular}

${ }^{*}$ Number calculated based on the results published by the authors.

of mosquitoes as vectors of Dirofilaria was not the same. There were five species of mosquitoes, Ae. punctor, Ae. diantaeus, Ae. sticticus, Ae. caspius and Cx torrentium, in which no infected samples were found. Absence of infection in Ae sticticus and Ae. punctor was probably associated with a small sample size (57 and 50 mosquitoes, respectively). Cx. torrentium rarely attack people, and with our collection method, the sample size was only three mosquitoes. However, of particular interest is the reason for the absence of infection in Ae. diantaeus and Ae. caspius, which were collected in sufficient numbers
(117 and 146 mosquitoes) and not in the natural forests. Another interesting finding was the absence of infection in Ae. diantaeus, which were mainly collected in the Nizhny Novgorod region, where other mosquito species of the same biotope were infected (SM2). In contrast to our results, it was reported that Ae. caspius was infected with $D$. repens in Italy [38] and Moldova [58], with D. immitis in Serbia [37], Portugal [25] and Hungary, based on one positive sample of $D$. repens and $D$. immitis out of 267 collected mosquitoes from four species [71]. The absence of infection in Ae. caspius in our 
collections may be explained by there being no infection or only slight infection at that particular collection point, since specimens of other species were also negative.

In four species (Ae. leucomelas, Ae. cataphylla, Ae. cinereus and Ae. excrucians), Dirofilaria were found only in the abdomens, indicating that its development did not reach an infective L3 stage (Table 2). Also, it should be highlighted that in three species of mosquitoes (Ae. cantans, Ae. communis, and Ae. vexans), there were positive signals for Dirofilaria simultaneously in the thorax-head and abdomen pools. This fact may indicate that mosquitoes could ingest the filariae at different times and repeatedly, and not all nematodes managed to complete the development cycle to become infective larvae and migrate to the front of the body. Similarly, it cannot be excluded that not all filariae reach the infectious stage due to possible defense mechanisms activated by host cells, such as encapsulation, melanization, and coagulation [12, 21, 34]. However, in all mosquito species, except Ae. aegypti where only one pool was infected, the percentage of positive thoraxhead pools was lower compared to abdomen pools.

According to published research, the development of Dirofilaria to the infective stage (L3) was recorded in Europe in the mosquito species Ae. caspius, An. maculipennis, Ae. vexans, Ae. geniculatus, Ae. albopictus, and Cx. pipiens (Table 4). On the basis of our results, eleven mosquito species are epidemiologically dangerous, when Dirofilaria undergo development to L3 (Table 2). Of particular interest are the species Ae. geniculatus, Ae. communis, Ae. intrudens, Ae. cantans and $C x$. modestus, in which L3 were found more than once. Ae. Aegypti, Ae. geniculatus, An. messeae and Ae. communis have host effectiveness values ranging from 1.3 to 4.76 . It should be noted that the efficacy of Ae. aegypti as a vector of Dirofilaria has been studied many times in laboratory conditions $[34,57,62]$, where the microfilariae developed to thirdstage larvae, but not in field-collected Ae. aegypti. In seven mosquito species, the host effectiveness was less than 1 (Table 2).

\section{Wolbachia and Dirofilaria infection in individual mosquitoes}

Most mosquito species uninfected with Wolbachia showed higher epidemiological potential for Dirofilaria transmission in all studied regions (host effectiveness 0.41-4.76; $\mathrm{EIR}=2.96-8.67$, average $\mathrm{EIR}=4.2)$. Ae. cinereus and $C x$. modestus pools that had Dirofilaria were free from Wolbachia (Table 3).

Dirofilaria DNA was detected in abdomen pools of both Wolbachia-infected and uninfected mosquitoes. This result shows that Wolbachia does not prevent the acquisition of Dirofilaria by mosquitoes in nature. However, in eight thorax-head pools, D. immitis DNA was only detected in Wolbachiauninfected mosquitoes. Moreover, after individual study of 11 thorax-heads from two Wolbachia positive Cq. richiardii abdomen pools, the $D$. immitis development was successful only in Wolbachia-free sample (Table SM4).

D. repens DNA in thorax-heads was found in 14 Wolbachia-uninfected and in only two Wolbachia-infected pools, in one of Ae. albopictus and in one of Cx. pipiens. We could not study mosquitoes from these two pools individually, so it is impossible to determine whether all the individuals in pool were infected with the bacterium, and to what ecological form (f. pipiens or f. molestus) of Cx. pipiens they belonged. Therefore, our findings do not prove a clear influence of bacteria on the development of Dirofilaria.

Nevertheless, the ratio of Dirofilaria-infective mosquitoes is much higher in Wolbachia-free mosquito specimens than in Wolbachia-infected, 22:2. Differences in the effects of different strains of Wolbachia were not recorded. However, given the small sample size of Dirofilaria-infected mosquitoes, further investigation into whether Wolbachia is present in individual $C x$. pipiens and Ae. albopictus mosquitoes carrying infective L3 stage larvae is required.

It is known that artificial bacterial transfer significantly increases the expression of immune genes, including those involved in the Toll and IMD immune pathways, enhances the mosquito's resistance to pathogens [5, 48, 49], and inhibits the development of filarial nematodes [1,33]. In contrast, it has been shown that native Wolbachia does not affect the induction of host immune pathways [17, 39]. As a hypothesis, it could be proposed that there is a resource competition in the host for metabolites, because both Dirofilaria [19, 30] and Wolbachia [68] require them for their development. It should be noted that any Wolbachia anti-pathogen effect is dependent on bacterial density [40], so the development of microfilaria to the infective stage may differ in each mosquito. The study of simultaneous infection of individual mosquitoes with Dirofilaria spp. and a bacterial symbiont, taking into account Wolbachia density, will help us understand the mechanism of Wolbachia interference in the transmission of Dirofilaria by mosquitoes.

In conclusion, Dirofilaria were found in 15 mosquito species. This is the first study conducted in Russia examining the mosquito species as potential vectors of $D$. immitis and D. repens. Out of 1095 pools studied, there were 114 positive abdomen pools and 34 positive thorax-head pools. The ratio of infected pools to infective pools was 3.35:1. Mosquitoes in central temperate regions are able to spread Dirofilaria no less than mosquitoes in the southern regions. This indicates that the presence of infected dogs has a greater effect on the maintenance of foci of dirofilariasis than temperature. In the forests, the circulation of pathogens occurs with less intensity than in human settlements in rural and urban areas. For the first time in Europe, Ae. aegypti, Ae. intrudens and Ae. communis mosquitoes have been studied as Dirofilaria vectors, in which EIR values ranged from 3.08 to 5.33. Our data showed that Ae. albopictus and Culex pipiens s.l. are not the most important vectors of Dirofilaria. The greatest epidemiological danger was represented by An. messeae, Ae aegypti, Ae. geniculatus, and Ae. communis. Ae. cantans might be added to this list given the considerable host effectiveness and the very high density.

Acknowledgements. We thank Vera Rakova and Ivan Patraman for the assistance in mosquito sampling and in carrying out certain molecular assays.

\section{Conflict of interest}

There is no conflict of interests. 


\section{Funding}

This work was supported by the Russian Foundation of Fundamental Research [grant N 16-04-00091].

\section{Supporting information}

SM1. Mosquitoes collected between 2013 and 2017. Information on the specificities and the coordinates of the sampling site, sampling date, total mosquito number and Dirofilaria screening results.

SM2. Mosquito infection with Dirofilaria spp. in specific sample sites. Information on the sampling date, mosquito species, pool size and Dirofilaria screening results.

SM3. Occurrence of Wolbachia in mosquito species. Information on the sampling region, mosquito number, pool size and Wolbachia screening results.

SM4. Comparison of simultaneous infection with Wolbachia and Dirofilaria individually.

Supplementary materials are available at https://www. parasite-journal.org/10.1051/parasite/2019002/olm.

\section{References}

1. Andrews ES, Crain PR, Fu Y, Howe DK, Dobson SL. 2012. Reactive oxygen species production and Brugia pahangi survivorship in Aedes polynesiensis with artificial Wolbachia infection types. PLoS Pathogens, 8(12), e1003075.

2. Arakeljan R, Kovtunov A, Bikov V, Shatalin V, Arakeljan E. 2008. Epidemiologic-episootologic features of three-member system of dirofilariasis (dog-mosquito-people) on the territory of Astrakhan region. Siberian Medical Journal, 7, 13-18 (in Russian).

3. Atyame CM, Delsuc F, Pasteur N, Weill M, Duron O. 2011. Diversification of Wolbachia endosymbiont in the Culex pipiens mosquito. Molecular Biology and Evolution, 28, 2761-2772.

4. Barashkova SV. 2011. Case of dirofilariasis in adolescent in Saint-Petersburg: Clinical and morphological characteristic. Journal Infectology, 3, 108-110 (in Russian).

5. Bian G, Joshi D, Dong Y, Lu P, Zhou G, Pan X, Xu Y, Dimopoulos G, Xi Z. 2013. Wolbachia invades Anopheles stephensis populations and induces refractoriness to Plasmodium infection. Science, 340(6133), 748-751.

6. Biskin Z, Duziu O, Yildirim A, Inci A. 2010. The molecular diagnosis of Dirofilaria immitis in vector mosquitoes in Felahiye district of Kayseri. Turkiye Parazitoloji Dergisi, 34(3), 200-205.

7. Bockova E, Rudolf I, Kocisova A, Betasova L, Venclikova K, Mendel J, Hubalek Z. 2013. Dirofilaria repens microfilariae in Aedes vexans mosquitoes in Slovakia. Parasitology Research, 112(10), 3465-3470.

8. Braig HR, Zhou W, Dobson SL, O’Neill SL. 1998. Cloning and characterization of a gene encoding the major surface protein of the bacterial endosymbiont Wolbachia pipientis. Journal of Bacteriology, 180(9), 2373-2378.

9. Bravo-Barriga D, Parreira R, Almeida APG, Calado M, BlancoCiudad J, Serrano-Aguilera FJ, Perez-Martin JE, SanchezPeinado J, Pinto J, Reina D, Frontera E. 2016. Culex pipiens as a potential vector for transmission of Dirofilaria immitis and other unclassified Filarioidea in Southwest Spain. Veterinary Parasitology, 223, 173-180.
10. Byakova OV, Maslennikova OV, Ermolina SA. 2014. Dirofilariosis dog in the Kirov region. Basic Research, 11, 1297-1300 (in Russian).

11. Cabanova V, Miterpakova M, Valentova D, Blazejova H, Rudolf I, Stloukal E, Hurnikova Z, Dzidova M. 2018. Urbanization impact on mosquito community and the transmission potential of filarial infection in Central Europe. Parasites \& Vectors, 11(1), 261.

12. Cancrini G, Frangipane di Regalbono A, Ricci I, Tessarin C, Gabrielli S, Pietrobelli M. 2003a. Aedes albopictus is a natural vector of Dirofilaria immitis in Italy. Veterinary Parasitology, 118(3-4), 195-202.

13. Cancrini G, Romi R, Gabrielli S, Toma L, Di Paolo M, Scaramozzino P. 2003b. First finding of Dirofilaria repens in a natural population of Aedes albopictus. Medical and Veterinary Entomology, 17(4), 448-451.

14. Cancrini G, Magi M, Gabrielli S, Arispici M, Tolari F, Dell'Omodarme M, Prati MC. 2006. Natural vectors of dirofilariasis in rural and urban areas of the Tuscan region, central Italy. Journal of Medical Entomology, 43(3), 574-579.

15. Cancrini G, Gabrielli S. 2007. Vectors of Dirofilaria nematodes: biology, behaviour and host/parasite relationships, in Dirofilaria immitis and D. repens in dog and cat and human infections, Genchi C, Rinaldi L, Cringoli G, Editors. Veterinary Parasitology and Parasitic Diseases, Department of Pathology and Animal Health, Faculty of Veterinary Medicine, University of Naples Federico II: Napoli, NA, Italy. p. 48-58. ISBN 9788889132142

16. Cancrini G, Scaramozzino P, Gabrielli S, Di Paolo M, Toma L, Romi R. 2007. Aedes albopictus and Culex pipens implicated as natural vectors of Dirofilaria repens in central Italy. Journal of Medical Entomology, 44(6), 1064-1066.

17. Caragata EP, Pais FS, Baton LA, Silva JBL, Sorgine MHF, Moreira LA. 2017. The transcriptome of the mosquito Aedes fluviatilis (Diptera: Culicidae), and transcriptional changes associated with its native Wolbachia infection. BMC Genomics, 18, 6.

18. Castillo JC, Reynolds SE, Eleftherianos I. 2011. Insect immune responses to nematode parasites. Trends in Parasitology, 27(12), 537-547.

19. Cotton JA, Bennuru S, Grote A, Harsha B, Tracey A, Beech R, Dovie SR, Dunn M, Hotopp JC, Holroyd N, Kikuchi T, Lambert O, Mhashilkar A, Mutowo P, Nursimulu N, Ribeiro JM, Rogers MB, Stanley E, Swapna LS, Tsai IJ, Unnasch TR, Voronin D, Parkinson J, Nutman TB, Ghedin E, Berriman M, Lustigman S. 2016. The genome of Onchocerca volvulus, agent of river blindness. Nature Microbiology, 2, 16216.

20. Cowling DW, Gardner IA, Johnson WO. 1999. Comparison of methods for estimation of individual-level prevalence based on pooled samples. Preventive Veterinary Medicine, 39(3), 211-225.

21. De Carvalho GA, Ramos RAN, Trindade Maia R, de Andrade CFS, Alves CL. 2018. Melanization of Dirofilaria immitis larvae in different culicid species. Journal of Arthropod-Borne Diseases, 12(1), 94-99.

22. de Pinho Mixao V, Mendes AM, Mauricio IL, Calado MM, Novo MT, Bello S, Almeida AP. 2016. Molecular detection of Wolbachia pipientis in natural populations of mosquito vectors of Dirofilaria immitis from continental Portugal: first detection in Culex theileri. Medical and Veterinary Entomology, 30, 301-309.

23. Dyab AK, Galal LA, Mahmoud AE, Mokhtar Y. 2016. Finding Wolbachia in Filarial larvae and Culicidae mosquitoes in Upper Egypt governorate. Korean Journal of Parasitology, 54 (3), 265-272.

24. Ermakova L, Nagorny S, Krivorotova E, Pshenichnaya N, Matina O. 2014. Dirofilaria repens in the Russian Federation: 
current epidemiology, diagnosis, and treatment from a federal reference center perspective. International Journal of Infectious Diseases, 23, 47-52.

25. Ferreira CA, de Pinho MV, Novo MT, Calado MM, Gonçalves LA, Belo SM, de Almeida AP. 2015. First molecular identification of mosquito vectors of Dirofilaria immitis in continental Portugal. Parasites \& Vectors, 8, 139. DOI: 10.1186/s13071015-0760-2.

26. Ganushkina LA, Rakova VM, Ivanova IB, Supriaga VG, Sergiev VP. 2014. Entomological monitoring of an area to assess Dirofilaria transmission risk. Meditsinskaia Parazitologiia i Parazitarnye Bolezni (Mosk), 3, 9-12.

27. Genchi C, Rinaldi L, Mortarino M, Genchi M, Cringoli G. 2009. Climate and Dirofilaria infection in Europe. Veterinary Parasitology, 163(4), 286-292.

28. Giangaspero A, Marangi M, Latrofa MS, Martinelli D, Traversa D, Otranto D, Genchi C. 2013. Evidences of increasing risk of dirofilarioses in southern Italy. Parasitology Research, 112(3), $1357-1361$.

29. Gouveia M. 2007. Susceptibility of Mosquito Vectors to Dirofilaria immitis on Madeira Island, Portugal. Tese Doutoramenteo Universidade da Madeira. Funchal, Portugal: Universidade da Madeira. 113 p. hdl.handle.net/10400.13/27.

30. Grote A, Voronin D, Ding T, Twaddle A, Unnasch TR, Lustigman S, Ghedin E. 2017. Defining Brugia malayi and Wolbachia symbiosis by stage-specific dual RNA-seq. PLoS Neglected Tropical Diseases, 11(3), e0005357.

31. Gutsevich AV, Monchadskii AS, Shtakelberg AA. 1970. Fauna of the USSR. Diptera. Mosquitoes. Nauka: Leningrad (in Russian).

32. Hertig M, Wolbach SB. 1924. Studies on rickettsia-like microorganisms in insects. Journal of Medical Research, 44(3), 329374.

33. Kambris Z, Cook PE, Phuc HK, Sinkins SP. 2009. Immune activation by life-shortening Wolbachia and reduced filarial competence in mosquitoes. Science (New York, NY), 326 (5949), 134-136.

34. Kartman L. 1953. Factors influencing infection of the mosquito with Dirofilaria immitis (Leidy, 1856). Experimental Parasitology, 2(1), 27-78.

35. Krivorotova EY. 2016. Xenomonitoring of dirofilariasis in the south and north-west of the Russian Federation. Parazitologiia, 50(5), 357-364 (in Russian).

36. Kronefeld M, Kampen H, Sassnau R, Werner D. 2014. Molecular detection of Dirofilaria immitis, Dirofilaria repens and Setaria tundra in mosquitoes from Germany. Parasites \& Vectors, 7(1), 30.

37. Kurucz K, Kepner A, Krtinic B, Zana B, Foldes F, Földes F, Bányai K, Oldal M, Jakab F, Kemenesi G. 2016. First molecular identification of Dirofilaria spp. (Onchocercidae) in mosquitoes from Serbia. Parasitology Research, 115(8), 3257-3260.

38. Latrofa MS, Dantas-Torres F, Annoscia G, Genchi M, Traversa D, Otranto D. 2012. A duplex real-time polymerase chain reaction assay for the detection of and differentiation between Dirofilaria immitis and Dirofilaria repens in dogs and mosquitoes. Veterinary Parasitology, 185(2-4), 181-185.

39. Li J, Wang N, Liu Y, Qiu S. 2018. Proteomics of Nasonia vitripennis and the effects of native Wolbachia infection on $N$. vitripennis. PeerJ, 6, e4905.

40. Lu P, Bian G, Pan X, Xi Z. 2012. Wolbachia induces densitydependent inhibition to dengue virus in mosquito cells. PLoS Neglected Tropical Diseases, 6(7), e1754.

41. Masetti A, Rivasi F, Bellini R. 2008. Mosquito-based survey for the detection of flaviviruses and filarial nematodes in Aedes albopictus and other anthropophilic mosquitoes collected in northern Italy. New Microbiolica, 31(4), 457-465.

42. Mckay T, Bianco T, Rhodes L, Barnett S. 2013. Prevalence of Dirofilaria immitis (Nematoda: Filarioidea) in mosquitoes From Northeast Arkansas, the United States. Journal of Medical Entomology, 50(4), 871-878.

43. Montarsi F, Ciocchetta S, Devine G, Ravagnan S, Mutinelli F, Frangipane di Regalbono A, Otranto D, Capelli G. 2015. Development of Dirofilaria immitis within the mosquito Aedes (Finlaya) koreicus, a new invasive species for Europe. Parasites \& Vectors, 8(1), 177.

44. Moodley K, Govin CN, Peer AKC, Westhuizen MVD, Parbhoo D, Ming Sun L, du Plessis DC, Frean JA. 2015. First detection of human dirofilariasis in south Africa. Infectious Disease Reports, 7(1), 5726.

45. Morchón R, Bargues MD, Latorre JM, Melero-Alcíbar R, PouBarreto C, Mas-Coma S, Simon F. 2007. Haplotype H1 of Culex pipiens implicated as a natural vector of Dirofilaria immitis in an endemic area of western Spain. Vector Borne and Zoonotic Disease, 7(4), 653-658.

46. Murata K, Yanai T, Agatsuma T, Uni S. 2003. Dirofilaria immitis Infection of a Snow Leopard (Uncia uncia) in a Japanese Zoo with mitochondrial DNA analysis. Journal of Veterinary Medical Science, 65(8), 945-947.

47. Nicolescu G, Linton YM, Vladimirescu A, Howard TM, Harbach RE. 2004. Mosquitoes of the Anopheles maculipennis group (Diptera: Culicidae) in Romania, with the discovery and formal recognition of new species based on molecular and morphological evidence. Bulletin of Entomological Research, 94(6), 525-535.

48. Pan X, Zhou G, Bian G, Lu P, Raikhel AS, Xi Z. 2012. Wolbachia induces reactive oxygen species (ROS)-dependent activation of the Toll pathway to control dengue virus in the mosquito Aedes aegypti. Proceedings of the National Academy of Sciences, 109(1), E23-E31.

49. Pan X, Pike A, Joshi D, Bian G, McFadden MJ, Lu P, Liang X, Zhang F, Raikhel AS, Xi Z. 2018. The bacterium Wolbachia exploits host innate immunity to establish a symbiotic relationship with the dengue vector mosquito Aedes aegypti. ISME Journal, 12(1), 277-288.

50. Paras KL, O'Brien VA, Reiskind MH. 2014. Comparison of the vector potential of different mosquito species for the transmission of heartworm, Dirofilaria immitis, in rural and urban areas in and surrounding Stillwater, Oklahoma, U.S.A. Medical and Veterinary Entomology, 28(Suppl 1), 60-67.

51. Ricci I, Cancrini G, Gabrielli S, Damelio S, Favia G. 2002. Searching for Wolbachia (Rickettsiales: Rickettsiaceae) in mosquitoes (Diptera: Culicidae): Large polymerase chain reaction survey and new identifications. Journal of Medical Entomology, 39, 562-567.

52. Rudolf I, Šebesta O, Mendel J, Betášová L, Bocková E, Jedličková P, Venclíková K, Blažejová H, Šikutová S, Hubálek Z. 2014. Zoonotic Dirofilaria repens (Nematoda: Filarioidea) in Aedes vexans mosquitoes, Czech Republic. Parasitology Research, 113, 4663-4667.

53. Ryabova T, Yunicheva Y, Markovich N, Ganushkina L, Orabei V, Sergiev V. 2005. Detection of Aedes (Stegomyia) aegypti L. mosquitoes in Sochi. Meditsinskaia parazitologiia i parazitarnye bolezni, 3, 3-5 (in Russian).

54. Sergiev VP, Supriaga VG, BronshteØn AM, Ganushkina LA, Rakova VM, Morozov EN, Fedianina LV, Frolova AA, Morozova LF, Ivanova IB, Darchenkova NN, Zhukova LA. 2014. Results of studies of human dirofilariasis in Russia. Meditsinskaia parazitologiia i parazitarnye bolezni, 3, 3-9 (in Russian). 
55. Shaikevich E. 2007. PCR-RFLP of the COI gene reliably differentiates $C x$. pipiens, $C x$. pipiens f. molestus and $C x$. torrentium of the Pipiens Complex. European Mosquito Bulletin, 23, 25-30.

56. Shaikevich E, Vinogradova E, Bouattour A, Almeida APG. 2016. Genetic diversity of Culex pipiens mosquitoes in distinct populations from Europe. Contribution of $C x$. quinquefasciatus in Mediterranean populations. Parasites \& Vectors, 9(1), 47.

57. Sulaiman I, Towson H. 1980. The genetic basis of susceptibility of infection with Dirofilaria immitis in Aedes aegypti. Annals of Tropical Medicine and Parasitology, 74, 635-646.

58. Sulesco T, von Thien H, Toderas L, Toderas I, Lühken R, Tannich E. 2016. Circulation of Dirofilaria immitis in Moldova. Parasites \& Vectors, 9(1), 627.

59. Sulesco T, von Thien H, Toderas L, Toderas I, Lühken R, Tannich E. 2016. Detection of Dirofilaria repens and Dirofilaria immitis DNA in mosquitoes from Belarus. Parasitology Research, 115, 3535-3541.

60. Tarello W. 2011. Clinical aspects of dermatitis associated with Dirofilaria repens in pets: a review of 100 canine and 31 feline cases (1990-2010) and a report of a new clinic case imported from Italy to Dubai. Journal of Parasitology Research.

61. Taylor MJ, Voronin D, Johnston KL, Ford L. 2013. Wolbachia filarial interactions. Cellular Microbiology, 15(4), 520-526.

62. Tiawsirisup S, Nithiuthai S. 2006. Vector competence of Aedes aegypti (L.) and Culex quinquefasciatus (Say) for Dirofilaria immitis (Leidy). Southeast Asian Journal of Tropical Medicine and Public Health, 37(suppl 3), 110-114.

63. Tumolskaya NI, Pozio E, Rakova VM, Supriaga VG, Sergiev VP, Morozov EN, Morozova LF, Rezza G, Litvinov SK. 2016. Dirofilaria immitis in a child from the Russia Federation. Parasite, 23, 37.

64. Vakalis N, Spanakos G, Patsoula E, Vamvakopoulos NC. 1999. Improved detection of Dirofilaria repens DNA by direct polymerase chain reaction. Parasitology International, 48, $145-150$.

65. Werren JH, Baldo L, Clark ME. 2008. Wolbachia: master manipulators of invertebrate biology. Nature Reviews. Microbiology, 6, 741-751.

66. Wilkerson RC, Linton Y-M, Fonseca DM, Schultz TR, Price DC, Strickman DA. 2015. Making mosquito taxonomy useful: a stable classification of Tribe Aedini that balances utility with current knowledge of evolutionary relationships. PLoS One, 10 (7), $\mathrm{e} 0133602$.

67. Wright JD, Barr AR. 1980. The ultrastructure and symbiotic relationships of Wolbachia of mosquitoes of the Aedes scutellaris group. Journal of Ultrastructure Research, 72, 52-64.

68. Wu M, Sun LV, Vamathevan J, Riegler M, Deboy R, Brownlie JC, McGraw EA, Martin W, Esser C, Ahmadinejad N, Wiegand C, Madupu R, Beanan MJ, Brinkac LM, Daugherty SC, Durkin AS, Kolonay JF, Nelson WC, Mohamoud Y, Lee P, Berry K, Young MB, Utterback T, Weidman J, Nierman WC, Paulsen IT, Nelson KE, Tettelin H, O'Neill SL, Eisen JA. 2004. Phylogenomics of the 235 reproductive parasite Wolbachia pipientis wMel: a streamlined genome overrun by mobile genetic elements. PLoS Biology, 2(3), e69.

69. Yildirim A, Inci A, Duzlu O, Biskin Z, Ica A, Sahin I. 2011. Aedes vexans and Culex pipiens as the potential vectors of Dirofilaria immitis in Central Turkey. Veterinary Parasitology, 178(1-2), 143-147.

70. Zhou W, Rousset F, O'Neil S. 1998. Phylogeny and PCR-based classification of Wolbachia strains using wsp gene sequences. Proceedings of the Royal Society B: Biological Sciences, 265 (1395), 509-515.

71. Zittra C, Kocziha Z, Pinnyei S, Harl J, Kieser K, Laciny A, Eigner B, Silbermayr K, Duscher GG, Fok E, Fuehrer HP. 2015. Screening blood-fed mosquitoes for the diagnosis of filarioid helminthes and avian malaria. Parasistes \& Vectors, $8,16$.

Cite this article as: Shaikevich E, Bogacheva A \& Ganushkina L. 2019. Dirofilaria and Wolbachia in mosquitoes (Diptera: Culicidae) in central European Russia and on the Black Sea coast. Parasite 26, 2. on all aspects of human and animal parasitology

Reviews, articles and short notes may be submitted. Fields include, but are not limited to: general, medical and veterinary parasitology; morphology, including ultrastructure; parasite systematics, including entomology, acarology, helminthology and protistology, and molecular analyses; molecular biology and biochemistry; immunology of parasitic diseases; host-parasite relationships; ecology and life history of parasites; epidemiology; therapeutics; new diagnostic tools.

All papers in Parasite are published in English. Manuscripts should have a broad interest and must not have been published or submitted elsewhere. No limit is imposed on the length of manuscripts.

Parasite (open-access) continues Parasite (print and online editions, 1994-2012) and Annales de Parasitologie Humaine et Comparée (1923-1993) and is the official journal of the Société Française de Parasitologie. 